\title{
Understanding English Speaking Practice in Public Schools in Kazakhstan: A Case Study in Almaty
}

\author{
ALMAGUL TUSPEKOVA \\ Universiti Kebangsaan Malaysia \\ tuspekova.almagul@gmail.com \\ ROSNIAH MUSTAFFA \\ Universiti Kebangsaan Malaysia \\ KEMBOJA ISMAIL \\ Universiti Kebangsaan Malaysia
}

\begin{abstract}
Teaching and learning of English as a spoken language in English as a Foreign Language (EFL) still remains a major concern in Asian context as evident from recent studies. The situation is similar in Central Asian classrooms where it received little attention. Specifically, this study investigates a classroom in a local public school in Kazakhstan through the lens of a teacher and the students during speaking activities. A case study qualitative approach was employed using interviews, classroom observations, and document analysis as data collection methods. In total, 21 individual interviews and 30 hours of classroom observations were conducted and recorded. Analyses and interpretations of data show that firstly the speaking activities lack in negotiation of meaning as they are predominantly aimed at predetermined monological performance-based speech. Secondly, out-of-school learning was prevalent among the majority of students at private learning centres. Also, selflearning at home was practiced by male students via interacting with foreign players in online video games and by female students via watching English movies. Thirdly, classroom interactions were accountable in facilitating and inhibiting the practice of speaking. Finally, there was a mismatch between the perceptions of the teacher and the students on the challenges of the speaking practice. The teacher indicated insufficient teaching hours and students' limited background knowledge, while the students emphasised the teacher's unwillingness to use English as a language of instruction and to practice impromptu speech in class. In summary, the findings highlight some of the apprehensions faced by the teacher and the students which reveals the current English speaking practice in Kazakhstani classroom.
\end{abstract}

Keywords: Speaking; spoken language; speaking activities; speaking practice; classroom learning

\section{INTRODUCTION}

Previous studies on teaching and learning of oral language in different EFL contexts were aimed at improving local learners' speaking skills either by understanding the reality of the classrooms or by using pedagogical interventions. Spoken English continues to be a major concern in Asian context as evident from recent studies conducted in Nepal (in Manzano 2018), Taiwan (in Fang et al. 2018), Sri Lanka (in Shashikala 2018), Turkey (in Basöz \& Erten 2018), China (in Yu 2019), Hong Kong (in Lee \& Chen 2019), Iran (in Shirkhani 2019), Malaysia (in Man et al. 2019), Pakistan (in Syed et al. 2019), and others. However, researches on spoken English language practice were under explored in Central Asian context which includes countries like Kazakhstan, Kyrgyzstan, Tajikistan, Turkmenistan, and Uzbekistan. This can be seen from studies in the Uzbekistani context which focused on a conceptual discussion of the issues related to teaching and learning of English in general (Hasanova 2007), and the challenges in implementing Communicative Language Teaching in schools (Hasanova \& Shadiyeva 2008). In Tajikistan, Olimnazarova (2012) investigated the use of students' linguistic repertoires in teaching English as a foreign language, while Bolander (2016) explored English language policy as an ideology in the country's multilingual environment. The study in Turkmenistani context discussed the role of English in the state's educational system (Ahn 
\& Jensen 2016), while in Kyrgyzstan the study by Remzi (2020) examined English language teaching methods in secondary comprehensive school classrooms. Although these studies provided valuable insights into these countries' foreign language education, little attention was given to the speaking component activities.

In Kazakhstani (KZ, henceforth) EFL context, previous studies predominantly focused on the role of the English language in relation to the country's trilingual education (Akynova et al. 2014; Jantassova 2015; Yeskeldiyeva \& Tazhibayeva 2015; Tussupbekova \& Enders 2016; Prilipko 2017). The speaking aspect was only addressed in Suleimenova's (2013) and Tleuov's (2016) studies with the former analysing the factors associated with speaking anxiety among high school students, while the latter examining teachers' beliefs and practices in teaching speaking. At this juncture, there remains a paucity of research investigating the speaking practice as a process through the lenses of both the students and teachers. Thus, this study sets out to explore 1) how speaking practice unfolds in a natural setting 2) how teacher and students behave and interpret the speaking process.

English is a foreign language in Kazakhstan despite its secondary role compared to the country's two official languages which are Kazakh and Russian. Over the past decades, there has been a growing interest in English language education because English was given the status of a "language of integration into the global economy". Kazakhstani President highlighted the importance of improving English speaking proficiency among KZ current generation of youths in facing global challenges. Henceforth, the Ministry of Education and Science has produced guidelines for teaching methodology for public schools and English teachers in KZ public schools have been encouraged to focus on the development of learners' speaking proficiency in English as a Foreign Language.

Despite the robust effort by the government to promote English in the country's educational sector, the outcome appears to be futile. For instance, in the English Proficiency Index ranking results for 2019 published by EF (English First) global education company, Kazakhstan's score in the EF Standard English Test was 43.83 (out of 100), which is considered as 'a very low proficiency band'. This is supported by Tleuov's (2016) research which highlighted the speaking of English remains "unencouraged domain of EFL education in Kazakhstani state secondary schools" (p. 252). The current standard of English speaking proficiency among students does not reflect sufficient teaching and learning of speaking component. Furthermore, it is essential to conduct a research to understand the underlying reasons for this phenomenon. Hence, this study seeks to bridge the research gap in understanding the classroom practice in speaking since little research has been carried out in the $\mathrm{KZ}$ context.

\section{LITERATURE REVIEW}

There are various aspects to speaking which makes it a multifaceted phenomenon. Based on this premise, this study dwells on its 'multifacedness' which refers to the overlapping of areas such as pragmatics, ethnography, syntax, semantics, prosody, phonetics, phonemics, and etcs. Hence, there is no single best approach to explore speaking activities given the context is classroom-based where learners come from different social backgrounds and language proficiency (Hughes \& Reed 2011). This reflects the present situation in KZ classrooms so this research is timely as it aims to investigate the English speaking practice by using Vygotsky learning theory (1978) which is a part of the sociocultural theory.

Vygotsky's theory allows the researcher to position the practice of speaking in a social context and examine it as a process or social event constructed by the actors (teacher and students). Some recent studies on speaking in Asian regions used this theory to show the 
phenomenon of speaking cannot be fully understood without considering the social and cultural context within which it is embedded. For example, Khajavy et al. (2016) revealed that the classroom environment directly affected Iranian students' motivation and confidence during participating in speaking activities. Similarly, Batiha et al. (2018) in Jordanian context and Macayan et al. (2018) in Filipino context discovered that a social aspect had an inhibiting effect on students' engagement in speaking, whereby students attributed their speaking anxiety to the fear of being critised by their classmates and their attitudes towards the teacher. On the other hand, the facilitating role of the social component was reflected in Chew et al. (2018) and Uztosun (2018) et al., where collaborative learning was found to foster students' engagement in communication activities among Taiwanese and Turkish students, respectively. The role of context was also highlighted in Syed and Kuzborska's (2018) study that showed the interplay of contextual, linguistic, psychological and physiological factors on Pakistani students' willingness to communicate in the classroom. Similarly, these factors were also identified by Riasati (2018) on Iranian students' participation in speaking practices and were categorised into two types such as environmental (situational) and individual. The documented recent studies showcase the importance of the classroom context that shapes the way learning unfolds. Therefore, it is imperative to understand the speaking practice in a Kazakhstani EFL classroom from a sociocultural perspective.

The practice of speaking in the context of local EFL classrooms where it is viewed as a learning process aimed at developing students' speaking skills in the English language. The term 'actors' and 'mediating means' (tools) were used by Vygotsky as tools to ensure the process occurs. Here, the actors are represented by the EFL teacher and students. The mediating means in the classroom refer to the speaking activities and interactions between the actors through which speaking practice is realised. In this study, activity refers to the oral practices, while interactivity relates to the interactions between teacher and students, and among students themselves. This concurs with Thornbury's (2005) idea that in a successful classroom setting learning requires both activity and interactivity. Hence, the role of mediating tools is significant in influencing individuals as they help learners to accomplish a task or to achieve a goal that cannot be attained without assistance (Lantolf 2000).

Another important aspect of the study is the factors that impact the practice of speaking in the classroom. While teachers expect students to actively engage in speaking activities, the reality may be far from ideal. On one hand, the complex nature of speaking imposes certain cognitive demands on learners: selection of words to express an idea, organisation of the relevant grammatical forms and verbalisation of the idea. This reflects Levelt's stages of speech production which he defines as formulation, conceptual preparation, and articulation of utterances (Levelt 1989). Also, there is an affective dimension of speech production that relates to learners' emotions connected to what they know, think, and feel. As Joseph LeDoux (1996 p. 25) posits, "minds without emotions are not really minds at all", which suggests a joint of cognitive and affective aspects of oral production. Because cognitive and affective processes occur in learners' minds, they are referred to as individual factors. Besides individual factors, the study also examines the contextual factors (classroom setting and classroom atmosphere) that might facilitate or inhibit students' participation in speaking activities.

Examination of the overarching context is essential in understanding classroom learning activities. This is emphasised by Duranti and Goodwin (1992) who argue that to understand a 'focal event', the researcher needs to 'look beyond the event itself to other phenomena within which the event is embedded' (p. 3). In this study, the focal event is the speaking practice or activity which is embedded in the classroom. Thus, it is crucial to investigate this process in relation to the setting where the speaking practice unfolds. This concept is summarised in the following diagrams (Figure 1 and Figure 2). 


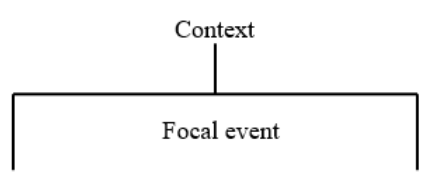

FIGURE 1. Representation of focal event and context in relation to each other Source: Duranti and Goodwin (1992, p. 3)

In the study, the above diagram can be conceptualized as follows (see Figure 2 below):

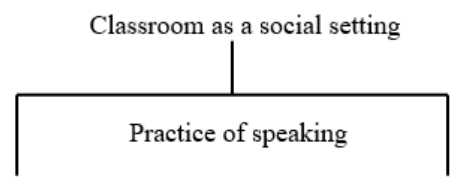

FIGURE 2. Positioning the practice of speaking in the classroom context Adapted from Duranti and Goodwin (1992, p. 3)

Finally, there is a need to explore students' and teachers' perceptions on teaching and learning of oral language. As they engage in the learning process, teacher and students develop their own subjective meanings on the in-class experiences, which, in turn, are likely to inform their classroom behaviour. A successful learning environment therefore can only be created by taking a closer look at the attitudes and motivations of both participants (Savignon 1976). Therefore, not only how the speaking practice occurs is significant, but also how teacher and students perceive "the activities in hand and their own place in them.

The discussion of the above concepts thus far is best represented in the following diagram (see Figure 3 below):

\section{Classroom as a social setting}

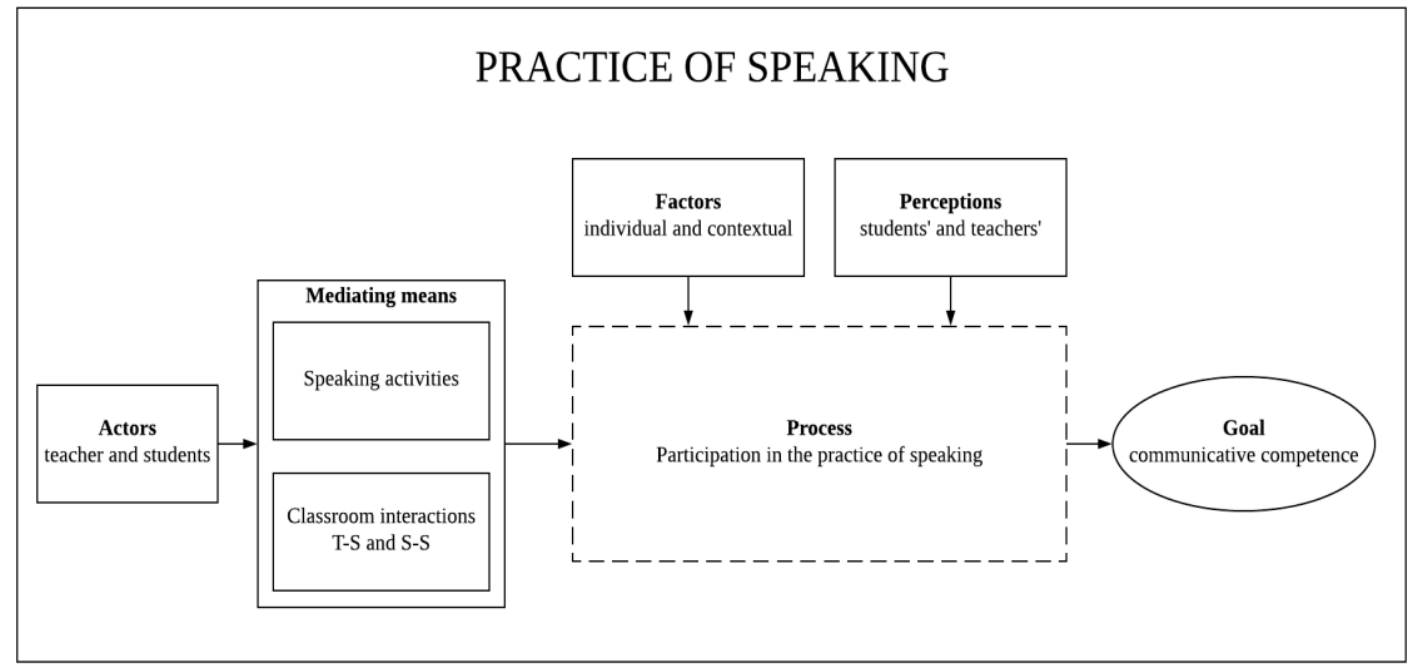

FIGURE 3. Conceptualised representation of the study's constructs 
Based on the diagram, this study aims to explore the nature of the English speaking practice and the perceptions of the teacher and students involved in it.

\section{METHODOLOGY}

A case study approach was employed to conduct this qualitative study. The rationale for this approach was that the study aimed at a thorough understanding of how speaking practice unfolds in its natural setting and how the teacher and students behave and interpret this process. The study was conducted in one public school in Almaty, the largest city in Kazakhstan. Informed consent was obtained from the school principal to enter the school premise and to conduct research at the site.

Three (3) Grade 9 classrooms in the school were selected for the study comprising 36 students in total. The rationale for the selection of Grade 9 classrooms is that in the Ministry's methodological guidelines (mentioned earlier) Grade 9 students are expected to be able to communicate in English in a spontaneous and meaningful manner. The rationale for the three classrooms is to strengthen the findings (Miles \& Huberman 1994) as this was an investigation of the multiple cases of the speaking practice, and there were three Grade 9 classes in the school in total.

\section{PARTICIPANTS}

Participants of the study were selected through purposive sampling as the criterion for students was that they must be Grade 9 students enrolled in English language classes, and for teachers - they must be non-native English language teachers of Grade 9 students. In Kazakhstan the average age of a $9^{\text {th }}$ grader is 14 to 15 years. Out of the total number of 36 students, 20 volunteered to participate in the individual interviews. As there were only two English teachers of Grade 9 in the school, both of them were approached, but only one agreed to participate in the study. At the outset of the study the selected English teacher provided the researcher with the information regarding the overall students' performance and their general characteristics. All the participants gave their consent to participate before the data collection process commenced. To ensure participants' confidentiality, they were given codes such as "P1(f)" or "P2(m)", meaning "Participant 1 (female)" and "Participant 2 (male)", respectively.

\section{DATA COLLECTION METHODS}

The study used interviews and classroom observations as the primary sources of data collection and documents as the secondary sources. In total, 21 semi-structured individual interviews were conducted: 20 with students and 1 with English teacher. All interviews were conducted in Russian language as preferred by the participants for convenience of expression. The interviews lasted for 45 minutes on average, they were audio-recorded and later transcribed in verbatim. Interview questions revolved around the study's focal constructs presented earlier. The participants were asked about their classroom speaking activities (likes, dislikes, preferences), their perceptions towards the English teacher and classmates, classrooms interactions, and the challenges they encounter during the learning process.

Along with the interviews, 30 hours of English lessons were observed by the researcher (10 observations in each Grade 9 classrooms). The researcher was a non-participant observer. Descriptive and reflective written fieldnotes were used as a means of recording since audio and video recordings were not permitted. The focus of observations was on the speaking practice 
that occurred in the classroom. Finally, documents such as the school's curriculum, the English textbook, and the teaching materials were used to corroborate the study's primary data.

Figure 4 below shows a visual representation of the school's English classroom setting:

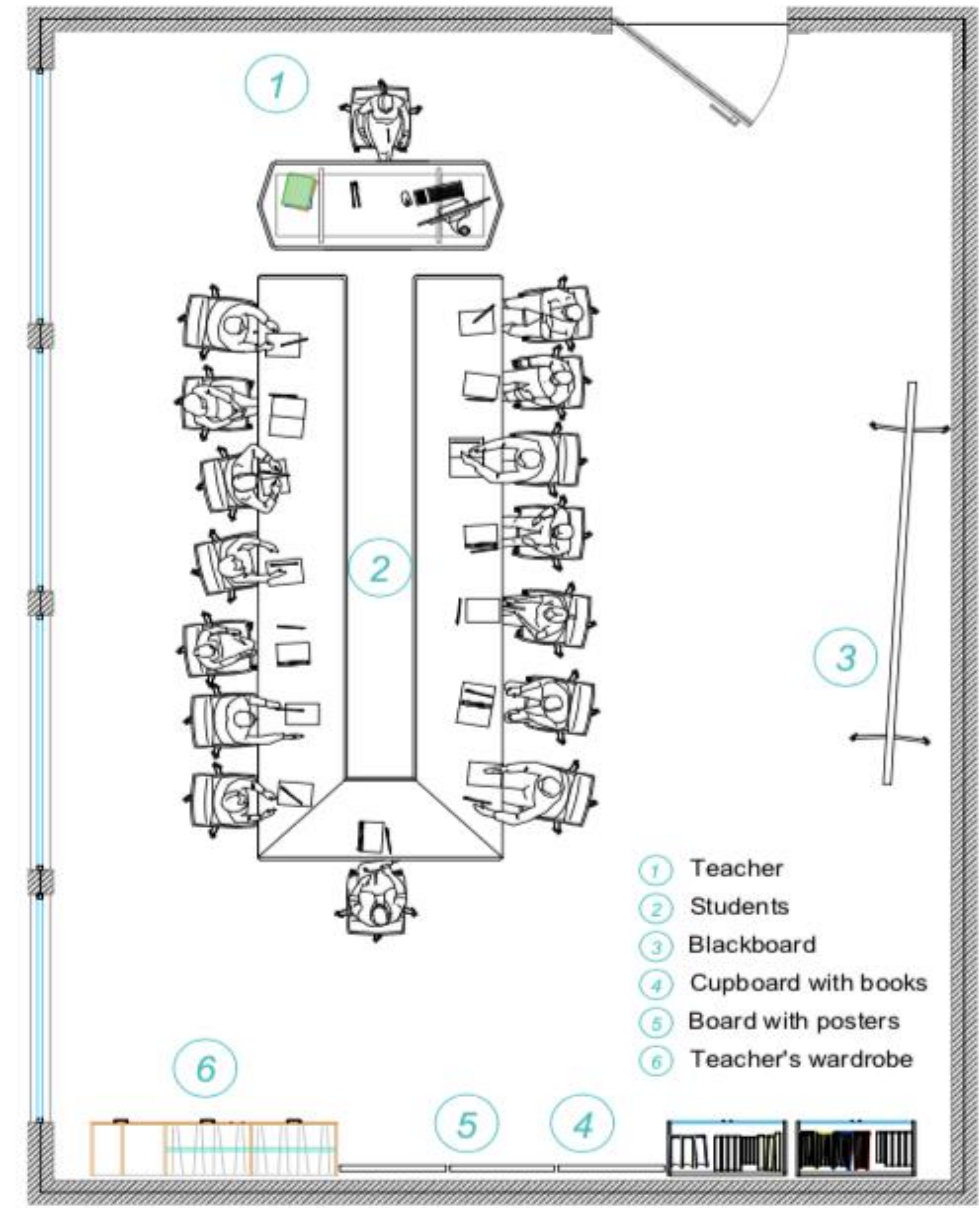

FIGURE 4. The study's English classroom setting

DATA ANALYSIS

Thematic analysis was used to analyse the data which was based on the guidelines by Braun and Clarke (2006). There are two approaches that guide a thematic analysis: inductive (datadriven) and deductive (theory-driven). The study used both approaches.

The researcher used the deductive approach at the beginning as there were a priori themes that served as a basic outline for the preliminary exploration of data. The a priori themes were identified based on the study's focal concerns such as speaking activities, classroom interactions, individual and contextual factors, and the teacher's and students' perceptions. In the next phase the data was coded within the pre-determined themes to further categorise them into potential sub-themes. Later in the analysis the researcher operated from the inductive stance as some pieces of the data comprised segments that did not fit into a preexisted frame, and therefore were coded and then grouped into newly emerged categories. Next the generated categories were analysed to examine how they could be combined to produce an overarching theme and to identify the relationships between them. As a result, several themes emerged. 


\section{FINDINGS AND DISCUSSION}

Only five themes from the data analysis are presented in this paper as they best address the central phenomenon.

\section{SPEAKING ACTIVITIES LACK NEGOTIATION OF MEANING}

The data from classroom observations showed that the predominant speaking activities were oral retelling of a text and question-answer exercise from the textbook. The former activity implied that a student would go to the teacher's table and retell a text from the English textbook that he prepared in advance. The text's volume ranged between 150 to 200 words and covered such topics as "Health and Beauty Products", "Entertainment", "Mass Media", "Cinemas in London", "The History of London", "Environmental protection", "Global Warming", "Flora and Fauna of Kazakhstan", and others. The student's classmates, meanwhile, did not pay attention to his speech as they were engaged in their own activities. If the student made mistakes in pronunciation, the teacher corrected him. Once he finished, the teacher would give him a corresponding mark for the presentation, and the student would go back to his seat. In a case of the latter activity, students read a question on a certain topic from the English textbook in turn and provided their responses. The analysis revealed that question-answer exercises in the textbook were mainly close-ended which require simple "Yes" or "No" answers from the students. This type of questions did not promote an explicit expression of ideas that might help students in practicing how to formulate, structure, and articulate speech utterances. Below are examples of such questions derived from the textbook:

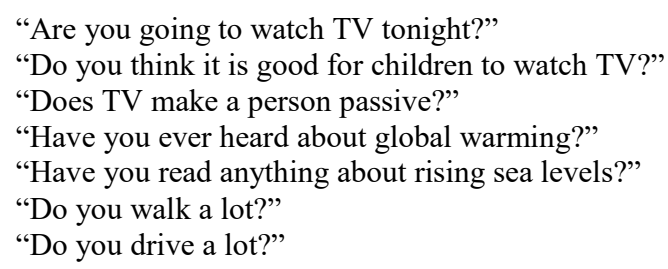

The prevalence of oral retelling and question-answer exercises indicate that the current speaking practices focus on talk as a performance, are non-interactive, and oriented towards the development of planned speech. This suggests that they are governed by a structural approach whereby the focus is primarily centred on manifestation of learners' knowledge of the language, rather than realisation of this knowledge to achieve certain communicative purposes. Thus, a functional approach appears to be neglected, which Littlewood (1981) defines as equally crucial in facilitating learners' speaking proficiency. As he argues, both structural and functional approaches should be used concurrently to ensure effective input and output. Therefore, it can be inferred that the students are limited in opportunities to engage in negotiation of meaning considered to be the core of the communication process. In other words, the classroom's structural activities do not allow students to engage in jointly produced interactions. This finding is consistent with Tleuov (2016) who revealed that the production of individual memorised speech was the basis of the speaking activities used by four English teachers in a Kazakhstani state school. This also concurs with the studies of Alsaedi (2012) and Gandeel (2016), which showed that teaching speaking in the Saudi Arabian context was characterised by a grammar-based approach with less emphasis on the meaningful use of language.

\section{IMPROMPTU SPEAKING IS THE MOST PREFERRED ACTIVITY FOR STUDENTS}

In line with the above theme, the practice of impromptu speech was found to be the principal point in the reported students' needs and interests pertaining to the classroom speaking 
activities. The majority of students highlighted the importance of reacting and responding quickly and meaningfully in conversations with foreigners without any preparation. These skills, however, as stated by the participants, were poorly practiced in school. To support this, some students shared their real-life situations when they experienced failures in spontaneous interactions. For example, in the excerpt below Participant 6 shares the story, when he was unable to converse with the receptionist at the hotel during the check-in process in Shanghai city, China:

I was with my parents in China, they don't speak English at all, nor they speak Chinese. My elder brother does speak English, but he wasn't there with us. Since I study English in school, the checkin was obviously on me. I was certain that I could easily talk to the receptionist, but when I came to him and he started to ask questions, I got stuck and couldn't say anything. I was frozen. I began structuring the sentence in my mind, and it took me quite a long time to actually say something. I wish we practiced spontaneous talks more.

(Excerpt from the interview transcript with P6 (m) translated from Russian)

Similarly, Participant 11 explains how she could not interact with her brother-in-law and nephews from Canada who came to visit Kazakhstan for a holiday (see excerpt below):

\begin{abstract}
My elder sister visited my mother and me during winter holidays. She lives in Canada, she is married to Canadian, and they have kids who speak English most of the time. She came with her husband and children for a week. I was so happy, but because I had problems speaking English with them, we barely talked. I really wanted to play with my nephews, but I couldn't interact with them, even on simple topics. It was very frustrating. That moment I realised how important it is to be able to speak with no preparations, just as it is, as it happens. We don't do it in our English lessons.
\end{abstract}

(Excerpt from the interview transcript with P11 (f) translated from Russian)

The excerpts show that Participant 6 was unable to use his speaking skills to transmit information to his interlocutor, while Participant 11 failed to engage in interpersonal communication to establish a positive relationship. It can be inferred that the students are concerned about maintaining talk as a transaction and talk as an interaction which constitutes essential functions of speaking along with the talk as performance discussed earlier (Brown $\&$ Yule 1983). In other words, students' preferences reflect the functional view on language, which remains unattended in the learning process. This finding suggests that there exist two contrasting realities in relation to the speaking practices: natural reality observed in the classroom and desired reality derived from the students' perceptions. This echoes with the study of Osterman (2014), which demonstrated that Japanese students preferred a more communicative-oriented approach in practicing speaking to the actual structural-based instruction. The revealed gap between the actual and preferred speaking activities supports the idea that it is crucial to understand learners' opinions on the classroom activities as they inform learners' behaviours, which subsequently affects learning outcomes. Overall, the mismatch between the two dichotomic realities draws attention to the need to incorporate functional-oriented techniques in teaching speaking as recently implemented by Xu \& Kuo (2018) in the Chinese context. The researchers used spontaneous group interaction strategies to enhance Chinese students' oral performance, which produced positive results at the end of the intervention. This accords with the study by Lee et al. (2019) on primary school ESL learners in Malaysia, which highlighted the need for teachers to use interactive activities to foster learners' practice of the target language and their active engagement in the learning process. 


\title{
STUDENTS PRACTICE OUT-OF-SCHOOL LEARNING TO IMPROVE SPEAKING
}

The limited nature of the classroom speaking activities was supported by the finding that many students practiced out-of-school learning to enhance their English oral skills, such as private tutorial courses and self-learning via technology. It was discovered that most students attended private classes because their parents encourage them to excel in English. Notably, these students were found to be high performers in their classes. On the contrary, the findings also revealed that some low performing students were not interested in enrolling in private courses, nor their parents considered it necessary. This illustrates the role of external factors such as parents' support in the learner's foreign language acquisition. The excerpt below shows how her mother's constant motivation helps Participant 3 (f) in learning English language:

My mom often talks about how English is important in today's world, that if I know English I
can study in any developed country and get a good job abroad. Sometimes when I'm lazy to do
my homework, she would remind me of how English will open many doors for me in the future.
It motivates me.

(Excerpt from the interview transcript with P3 (f) translated from Russian)

The excerpt confirms that parental engagement contributes to the learners' enthusiasm in learning the foreign language. This finding is consistent with those of Soomro (2016) and Kalayci and Öz (2018) whose studies confirmed that in Pakistani and Turkish contexts parents' motivation serves as a positive reinforcement for the students to actively engage in the learning process.

Besides private tutorials, many students reported using modern technologies to boost their speaking skills. The students used computers or mobile phones as self-learning tools to practice English at home. Interestingly, the gender aspect has emerged here. Male students reported using interactions with foreign players in online video games as an effective tool to practice oral language. Female students, on the other hand, noted watching English movies with subtitles as their most preferable self-learning aid. Below are the interview excerpts demonstrating the emerged gender aspect:

I usually spend around 2 hours a day playing video games on my computer. It helps me to ease the stress after school and practice my English at the same time. I speak with players from Canada, Prague, India, Australia, China... From all over the world. It's so cool! I learned many slang words from the game. At first it's hard to grasp the meaning, but I check it in Google, memorise, and then try to use it in my speech too.

(Excerpt from the interview transcript with P7 (m) translated from Russian)

\begin{abstract}
When I have free time, I watch movies in English with English subtitles for better understanding. Of course I'm not that good at English to understand everything the movie characters say, but it really helps me because I can hear how native speakers talk and what words they use. It's like you combine business with pleasure: you learn something and at the same time you enjoy the movie.
\end{abstract}

(Excerpt from the interview transcript with P7 (f) translated from Russian)

This finding highlights the role of the education-entertainment approach in stimulating learners to engage in the learning process beyond the academic context. It also shows the facilitating role of modern technologies in learning a foreign language, which can be employed by the teachers alongside conventional teaching methods. This is clearly demonstrated in the study of Ulusoy and Demirbilek (2013), which revealed that the use of situation comedy video (sitcom) as a classroom activity increased Turkish students' selfconfidence and participation in the English speaking practice. 


\section{CLASSROOM INTERACTIONS ARE BOTH FACILITATING AND INHIBITING}

Data from observations and interviews revealed two principal findings in relation to the classroom interactions. Firstly, most classroom interactions between the teacher and students and students themselves occurred in the Russian language. Secondly, the findings showed that such interactions had both positive and negative influence in relation to the classroom speaking practice.

The facilitating role of interactions was reflected in the teacher-student relationships. Students admitted that frequent conversations with their English teacher on different extracurricular topics contributed to their comfortable feelings in class, which, in turn, promoted a safe atmosphere of the learning context. This was supported by students' descriptions of English lessons as "funny", "interesting", "relaxing", and "pleasant". This also created a good rapport between the teacher and students, which according to the latter is significant in the learning process. They mentioned that because at the present moment they are at the transitional stage of adolescence and therefore are vulnerable, it is crucial for them to have an understanding adult. This supports the significance of the affective dimension pertaining to the learners' view of a good teacher.

However, classroom interactions were also found to have an inhibiting effect on the learning process. Because interactions were held in learners' $\mathrm{L} 1$ and were recurrent and prolonged, students' attention deviated from the learning process. There were many occasions during English speaking practice when the teacher and students would start a discussion about something irrelevant in L1 in a humorous manner, and this interaction would last for five to ten minutes, resulting in students' disruptive behaviour. Notably, several students commented that loud noises in class could lead to poor concentration and even headaches. Some participants claimed that they would like such interactions to occur in English as a perfect opportunity to practice their speaking skills. This is evident from the excerpt below:

It would be so nice if we could use English in conversations with our teacher. We always speak in
Russian when there is a 'hot' topic we want to discuss with the teacher, and she too never demands
that we express our ideas in English. I think we are both to blame, I mean students and teacher. We
really enjoy making jokes and laugh with her, and I guess she likes that too. But it's a waste of our
time that we could use it for the real practice of English.

(Excerpt from the interview transcript with P3 (f) translated from Russian)

This finding suggests that there is a possibility to diminish the negative impact of classroom interactions on the practice of speaking through gradual incorporation of English language into the classroom talks by joint efforts of teacher and students.

\section{MISMATCH BETWEEN TEACHER'S AND STUDENTS' PERCEPTIONS ON THE SPEAKING PRACTICE}

Interview findings showed that the teacher and students held different opinions on the pitfalls of the classroom speaking practice. From the teacher's point of view, lack of oral language learning in Grade 9 classrooms was attributed to two factors: insufficient teaching hours (only 2 hours of English a week) and learners' limited background knowledge. The teacher argued that she could not employ diverse speaking activities in the classroom because of the limited time assigned to one lesson. Besides, she remarked that many students were unable to express their ideas not only in the foreign language, but also in their L1 due to the poor knowledge in general subject matters. This was reflected in the interview excerpts below:

\footnotetext{
I have 15 students in class and only 40 minutes in total to explain new grammatical topics and practice speaking. If I give them a group discussion, we wouldn't manage to finish this activity before the class ends. Just two hours of English per week to really practice oral language is not enough given that each of 15 students must speak and I have to attend to their speech.
} 
Nowadays students don't want to read books or learn new things. If you ask them to reflect on a topic, they will just keep quiet and say nothing. They don't have an interest in talking about worldwide matters. How can I ask them to discuss something in English if they cannot form their ideas in their own language?

(Excerpts from the interview transcript with the teacher translated from Russian)

Students, on the other hand, emphasised the teacher's unwillingness to use English as a language of instruction in class and her reluctance to allow students to practice spontaneous speech. Students argued that if the teacher used English more frequently and required the same from the students, they would have considerably progressed in speaking proficiency. In addition, several students stated that in some cases when they intend to give an explicit answer on the question, the teacher interferes saying that they are only required to respond with Yes or No answer. This is shown in the excerpt below:

Just recently there was a situation when I wanted to talk about my visits to the theatre. In English. I
started my speech, but suddenly the teacher interfered and said that the question did not imply any
explanations, only Agree or Disagree. I was like... Okay. I wonder why she didn't allow me to
continue, but maybe we never had much time for the discussion, because she later gave us some
written exercises to do.

(Excerpt from the interview transcript with P15 (m) translated from Russian)

The discrepancies in the participants' subjective perspectives draw attention to the importance of constructive dialogue between the teacher and students on the problematic issues they would like to be addressed and changed.

\section{CONCLUSION}

The purpose of this study was to investigate the current English speaking practice in a local public school in Kazakhstan. Firstly, the study has shown that the structural approach dominates the practice of speaking in the classroom, whereby restraining students from mastering their transactional and interactional speaking skills. In addition, the findings revealed a mismatch between the teaching practice and learners' learning expectations in achieving overall speaking proficiency. This suggests the need to balance the opposing realities by incorporating more functional-based activities in the teaching approach. It also shows the significance of understanding learners' perspectives to ensure an effective learning environment. Secondly, the study highlighted the dual nature of classroom interactions which should be further exploited through a more balanced and flexible approach incorporating Russian and English languages. Thirdly, the study provided important insights into the role of parental support in the learning process and emphasised the potential usefulness of modern technologies in promoting active student engagement in the learning process. Technologybased interactive activities can be integrated into the classroom learning to increase students' interest and motivation to participate in speaking practices. Finally, the study emphasised the importance of dialogues between the teacher and students to enable the construction of mutual understanding, thereby promoting meaningful learning in the classroom. In summary, the findings contribute to the understanding of the pitfalls of the current English speaking practice in the Kazakhstani classroom context.

In conclusion, the study argues that it is crucial to investigate the reality of a classroom as it unfolds naturally and how it is perceived by teachers and students who complement each other in the classroom processes. Without empirical data it is quite impossible to understand the existing issues in the educational sector that can be further addressed for successful implementation of the top-down policies. 


\section{ACKNOWLEDGEMENT}

The present paper was presented at the Multi-Literacies Special Group 2019 Conference (MuLSIG'19), at School of Language Studies and Linguistics, Universiti Kebangsaan Malaysia, on 20 November 2019.

\section{REFERENCES}

Ahn, E. S. \& Jensen, A. (2016). Language Teaching in Turkmenistan: An autoethnographic journey. Language Change in Central Asia, Vol. 106, 59.

Akynova, D., Zharkynbekova, S., Agmanova, A., Aimoldina, A., \& Dalbergenova, L. (2014). Language choice among the youth of Kazakhstan: English as a self-representation of prestige. Procedia-Social and Behavioral Sciences, Vol. 143, 228-232.

Alsaedi, A. (2012). The teaching of EFL speaking in developed secondary public schools for females in Saudi Arabia: A case study. Unpublished PhD dissertation, School of Humanities, University of Southampton, United Kingdom.

Allwright, R. L. (1984). The importance of interaction in classroom language learning. Applied linguistics, Vol. 5(2), 156-171.

Basöz, T. \& Erten, I. H. (2018). Investigating tertiary level EFL learners' willingness to communicate in English. English Language Teaching, Vol. 11(3), 78-87.

Batiha, J. M., Mustaffa, R. M. \& Noor, N. M. (2018). Foreign language speaking anxiety of Jordanian freshman English learners (Kebimbangan bertutur dalam bahasa Asing oleh pelajar bahasa Inggeris tahun pertama Jordan). Akademika, Vol. 88(1), 153-165.

Braun, V. \& Clarke, V. (2006). Using thematic analysis in psychology. Qualitative Research in Psychology, Vol. $3(2), 77-101$.

Bolander, B. (2016). English language policy as ideology in multilingual Khorog, Tajikistan. In Discursive approaches to language policy (pp. 253-274). Palgrave Macmillan: London.

Chew, S. W., Fang, W. C., Hsu, C. N. \& Chen, N. S. (2018). Effects of reciprocal feedback on EFL learners' communication strategy use and oral communicative performance. In Challenges and Solutions in Smart Learning (pp. 31-39). Springer: Singapore.

Duranti, A. \& Goodwin, C. (Eds.). (1992). Rethinking context: Language as an interactive phenomenon (No. 11). Cambridge University Press.

Fang, W. C., Cassim, F. A., Hsu, C. N. \& Chen, N. S. (2018). Effects of reciprocal peer feedback on EFL learners' communication strategy use and oral communication performance. Smart Learning Environments, Vol. $5(1), 11$.

Gandeel, A. M. (2016). English language teachers' beliefs and practices regarding the teaching of speaking. Doctoral dissertation, University of Leeds, England.

Hasanova, D. (2007). Teaching and learning English in Uzbekistan. English Today, Vol. 23(1), 3-9.

Hasanova, D. \& Shadieva, T. (2008). Implementing communicative language teaching in Uzbekistan. TESOL quarterly, Vol. 42(1), 138-143.

Jantassova, D. (2015). The solution of teaching English as a foreign language integrating with Kazakh and Russian languages to students of Kazakhstan technical universities. Procedia-Social and Behavioral Sciences, Vol. 177, 136-141.

Hughes, R. \& Reed, B. S. (2016). Teaching and Researching Speaking. Routledge.

Kalayci, G. \& Öz, H. (2018). Parental involvement in English language education: Understanding parents' perceptions. Online Submission, Vol. 5(4), 832-847.

Khajavy, G. H., Ghonsooly, B., Hosseini Fatemi, A. \& Choi, C. W. (2016). Willingness to communicate in English: A microsystem model in the Iranian EFL classroom context. Tesol Quarterly, Vol. 50(1), 154180.

Lantolf, J. P. (Ed.). (2000). Sociocultural Theory and Second Language Learning, Vol. 78(4). Oxford University Press.

Lee, M. C. L., Krishnamoorthy, K. \& Rong, Y. J. (2019). The role of negotiated interaction in L2 vocabulary acquisition among primary ESL learners. 3L: Language, Linguistics, Literature ${ }^{\circledR}$, Vol. 25(2).

Levelt, W. J. (1992). Accessing words in speech production: Stages, processes and representations. Cognition, Vol. 42(1-3), 1-22.

LeDoux, J. (1996). Emotional networks and motor control: a fearful view. In Progress in brain research, Vol. 107 (pp. 437-446). Elsevier.

Li, H. P. \& Chen, H. C. (2019). Intelligibility and comprehensibility of the Filipino English accent to Hong Kong English speakers. 3L: Language, Linguistics, Literature®, Vol. 25(1). 
Littlewood, W. \& William, L. (1981). Communicative Language Teaching: An introduction. Cambridge University Press.

Macayan, J. V., Quinto, E. J. M., Otsuka, J. C. \& Cueto, A. B. S. (2018). Are Filipino students' L2 learning goals performance-or mastery-oriented? An explanatory sequential analysis. GEMA Online® Journal of Language Studies, Vol. 18(1).

Man, C. F., May, A. L. J., Sharif, S., Singh, S. \& Singh, B. (2019). Exploring the use of drama-based activities as a learning tool in English oral proficiency development among students from non-Malay-medium nation schools: A preliminary study. International Journal of Academic Research in Business and Social Sciences, Vol. 9(6).

Manzano, B. A. (2018). Examining the oral communication strategies used by a group of Nepalese adult learners in an ESL context. 3L: Language, Linguistics, Literature ${ }^{\circledR}$, Vol. 24(1).

Miles, M. B. \& Huberman, A. M. (1994). Qualitative Data Analysis: An Expanded Sourcebook. Thousand Oaks, CA: Sage Publications.

Olimnazarova, T. (2012). Using students' linguistic repertoires for teaching English as a Foreign Language in Tajikistan. Unpublished TEFL dissertation, University of Birmingham, United Kingdom.

Osterman, G. L. (2014). Experiences of Japanese university students' willingness to speak English in class: A multiple case study. SAGE Open, Vol. 4(3), 1-13.

Prilipko, A. (2017). Managing implementation of English medium of instruction in higher education in Kazakhstan: Practices and challenges. Doctoral dissertation, Nazarbayev University Graduate School of Education, Kazakhstan.

Remzi, A. D. S. Î. Z. (2020). Comparative analysis of foreign language teaching methods of 5-8 grades pupils in comprehensive schools of Kyrgyzstan and Turkey (on the example of English language). Doctoral dissertation, Bishkek Humanities University named after K. Karasayev, Moldova.

Riasati, M. J. (2018). Willingness to speak English among foreign language learners: A causal model. Cogent Education, Vol. 5(1), 1455332.

Savignon, S. J. (1976). Communicative competence 1976: Theory and classroom practice. In Esitelmä Konferenssissa Central States Conference on the Teaching of Foreign Languages, Vol. 23.

Shashikala, H. P. L. W. (2018). Exploring task-based approach to teaching oral communication skills in English to Sri Lankan undergraduate students. Journal of Literature and Art Studies, Vol. 8(6), 932-945.

Shirkhani, S., Meigouni, M. M. \& Alsadat, E. (2019). Oral communication strategies used by Iranian EFL learners and their relationship with the learners' self-efficacy beliefs and anxiety level. Research in English Language Pedagogy, Vol. 8(1), 11-20.

Soomro, N. H. (2016). Towards an understanding of Pakistani undergraduates' current attitudes towards learning and speaking English. Doctoral dissertation, University of Glasgow, Scotland.

Suleimenova, Z. (2013). Speaking anxiety in a foreign language classroom in Kazakhstan. Procedia-Social and Behavioral Sciences, Vol. 93, 1860-1868.

Syed, H. \& Kuzborska, I. (2018). Dynamics of factors underlying willingness to communicate in a second language. The language learning journal, 1-20.

Syed, N. M., Quraishi, U. \& Kazi, A. S. (2019). English Language Textbook and Development of Oral Communicative Competence in Grade VIII Students of Public Sector Schools in Punjab. Bulletin of Education and Research, Vol. 41(1), 105.

Thornbury, S. (2005). How to teach speaking. Longman.

Tleuov, A. (2016). The teaching of speaking: An investigation into the relationship between teachers' beliefs and practices in Kazakhstani state secondary school EFL classrooms. Doctoral dissertation, University of Bath, United Kingdom.

Tussupbekova, M. \& Enders, P. (2016). Linguistic Landscape in Kazakhstan. International Education and Research Journal, Vol. 2(2).

Uztosun, M. S., Skinner, N. \& Cadorath, J. (2018). An action research study into the role of student negotiation in enhancing perceived student engagement during English speaking classes at university level in Turkey. Educational Action Research, Vol. 26(1), 106-126.

Ulusoy, G. \& Demirbilek, M. (2013). The effects of using situation comedy video on English speaking. The Anthropologist, Vol. 16(1-2), 351-361.

Vygotsky, L. S. (1978). Mind in society: The development of higher psychological processes. Cambridge, MA: Harvard University Press.

Xu, J. \& Kou, J. (2018). Group interaction strategies and students' oral performance in Chinese EFL classrooms. TESOL Quarterly, Vol. 52(1), 198-209.

Yeskeldiyeva, B. Y. \& Tazhibayeva, S. Z. (2015). Multilingualism in modern Kazakhstan: New challenges. Asian Social Science, Vol. 11(6), 56.

Yu, Y. (2019). Problems in and solutions to oral English teaching in rural middle school—a case study in ZhaoCheng Middle School. Journal of Language Teaching and Research, Vol. 10(2), 372-382. 